\title{
Hvordan tjente de koranske hedninge til livets ophold?
}

\author{
Af Patricia Crone
}

Denne artikel undersøger de oplysninger, som gives i Koranen om de måder hvorpå hedningene, som budbringeren Muhammad prædikede for, tjente til livets ophold. Den viser, at Koranen beskriver dem som agerbrugsfolk og søfolk. Koranen specificerer sjældent formålet med deres virksomhed på havet, men nogle gange gør den klart, at det var fiskeri. De troende beskrives ligeledes som agerbrugsfolk i nogle afsnit, men oftere er de fremstillet som handelsfolk, især i de medinensiske suraer, hvor der også prædikes for dem med metaforer fra handelslivet.

Engelske studerende, der arbejder med islamiske emner, får ofte stillet en skriftlig opgave, der går ud på at kommentere følgende udsagn: "Koranen er den eneste pålidelige kilde til at forstå islams opståen”. De studerende besvarer typisk opgaven ved at gøre rede for den kanoniske teksts tilblivelse og desuden bemærke, at uanset hvordan vi betragter processen, er Koranen ikke en kilde, som er rig på historiske detaljer. Det er der ikke mange, som vil være uenige med dem i. Som alle ved, læser historikere, der beskæftiger sig med Profetens liv og samtid, Koranen sådan, som den forklares i tafsîr; heri findes de navne, datoer, fortællinger og andet supplerende materiale, som de har brug for. Det er som regel metoden, selv når forskerne tror, at de kun bruger Koranen. Men vi er muligvis nået til et punkt, hvor vi er begyndt at undervurdere bogens værdi som kilde. Den er bestemt ikke rig på historiske vidnesbyrd, men vi plejer normalt heller ikke at presse oplysninger ud af den, formodentlig fordi overfloden af eksegetisk materiale gør det unødvendigt. Da der er så mange tafsîr-, hadîth- og sîra-værker at beskæftige sig med, begynder man at tænke på udsagnene i Koranen, som om de blot var overskrifter, hvortil selve substansen skal findes andre steder. Dette er helt i orden for historikere, der beskæftiger sig med læsernes reaktioner på bogen, men det er åbenlyst ikke godt nok for de forskere, der er interesseret i det samfund, som bogen opstod i. I det følgende vil jeg ignorere den eksegetiske tradition for kun at se på Koranen selv med henblik på at besvare et simpelt spørgsmål: Hvilket indtryk giver den af den måde, hvorpå hedningene (al-mushrikûn, sing. mushrik) - de mennesker, den tager afstand fra - tjente til livets ophold? 


\section{Agerbrug}

I sura 36 bliver Profeten pålagt at advare et folk, hvis fædre ikke var blevet advaret, og som både var uopmærksomme og afvisende; advaret eller ej nægtede de at tro; de hånede i stedet Budbringeren (36:6-10, 30). Blandt de tegn, som Budbringeren anvender for at overbevise disse stædige mennesker, er det, at Gud giver den døde jord nyt liv og får det korn (habban), de spiser, til at spire tillige med daddelpalmelunde og vindruer (jannât min nakhîl wa-a nâb), og Han får kilder til at vælde frem deri, således at de kan spise af frugten. "Det er ikke deres hænders værk. Er de ikke taknemmelige?", siger Han (v.35). Den samme pointe understreges i 56:63f: "Hvad mener I om jeres pløjemark? Er det jer, der sår den til, eller sår Vi den till?" De vantro i disse tekststykker er agerbrugere, som er så tåbelige at forestille sig, at det er dem, der får korn, daddelpalmer, druer og lignende til at gro. De ligger under for menneskets tilbøjelighed til hovmod, for i virkeligheden er det Gud, der får sådanne ting til at fremkomme.

Man bliver mildt overrasket over disse tekststykker, idet beboerne i Mekka, som disse stædige mennesker traditionelt identificeres med, for enhver islamforsker kendes som handelsmænd, hvis by befandt sig i et goldt område. Men dette er kun to ud af mange tekststykker i Koranen, der lader formode, at Profetens modstandere var agerbrugere, hvad de så end ellers var derudover. Guds genopvækkelse af den døde jord er et fremtrædende tema, både set som et tegn på Hans ærefrygtindgydende magt og som et bevis på genopstandelsen. Der henvises desuden i overvældende grad til dyrkede planter snarere end til de blomster, der vokser frem i ørkenen om foråret, eller til anden vild vegetation. Gud får frodige haver (hadâ'iq dhât bahja) til at gro (27:60; jf. 80:30). Han sender regnen, der frembringer planter (nabât) af alle slags, heriblandt bladgrønsager (khadir), korn (habb), daddelpalmer (nakhl) og haver (jannât) med vindruer ( $\left.a^{\prime} n a \hat{b}\right)$ ), oliven (al-zaytûn) og granatæbler (al-rummân) (6:99) eller simpelthen frugter af alle slags (7:57, jf. 14:32). Andre tekststykker nævner korn og (andre) planter (78:15), haver, korn og daddelpalmer (50:9f), daddelpalmer og vindruer (16:67; 23:19), daddelpalmer, korn, vindruer og oliven (16:11) og vindruer, dadler, oliven, frugt og foder, der alle er "til 
nytte for jer og jeres kvæg” (matâ'an lakum wa-li-an 'âmikum) (80:27-32). Her siges det dog ikke eksplicit, at de vantro selv dyrker sådanne ting.

At de var agerbrugsfolk, ses ikke desto mindre tydeligt af det faktum, at de havde agerbrugsritualer, som Budbringeren bestemt ikke synes om:

De sætter en andel af til Gud af det høstudbytte og kvæg, Han har skabt, og siger: "Dette er til Gud - hævder de da!", og dette er til dem, vi sætter ved Guds side". Det, der er bestemt for dem, som de sætter ved Guds side, går ikke til Gud, og det, der er bestemt for Gud, går alligevel til dem, som de sætter ved Guds side. (6:136)

De siger: "Dette er kvæg og afgrøde, der er tabu (hijr). Ingen må spise deraf undtagen den, som vi vil - det hævder de". (6:138)

Ritualet synes at bestå i en indvielse af agerdyrkningens første afgrøder og husdyrenes første afkom til det guddommelige, og det er et af de mange tekststykker, som viser, at hedningene troede på den samme Gud som Budbringeren. ${ }^{2}$ Tilsyneladende blev de portioner, der var indviet til Gud og Hans 'associerede' efterladt, for at blive spist af 'hvem Gud nu end ønskede' hvilket måske ville sige fattige og rejsende. Det var under alle omstændigheder forbudt for ejerne af de første afgrøder/afkom selv at spise dem.

Budbringeren svarer dels ved at benægte, at Gud ville modtage noget af det (det hele skulle gå til de 'associerede', det vil sige de underordnede guddommelige væsner, som her implicit identificeres som dæmoniske), og dels ved at fremføre, hvordan man rent faktisk burde opføre sig. Han gentager, at det er Gud, som er årsag til, at haverne, daddelpalmerne (al-nakhl), forskellige typer frøsæd (zar), oliven (al-zaytûn) og granatæbler (al-rummân) gror, og han tilføjer:

Spis af deres frugt, når de bærer, og giv, hvad I har pligt til (haqqahu), når høsten er inde. I må ikke ødsle! Gud elsker ikke de ødsle. Og af kvæg, både lastdyr og ungdyr - spis blot af det, som Gud har forsynet jer med, og følg ikke i Satans fodspor! (6:141f) 
Endnu engang er det tydeligt, at vi befinder os i et agerbrugssamfund. Både de vantro og de troende har marker, haver og kvæg; begge parter høster korn, oliven og granatæbler, men de har forskellige syn på, hvad Gud ønsker, at de skal gøre med høsten.

Hedningene havde også andre ritualer, som havde at gøre med kvæg. Der fandtes dyr, som det var forbudt at ride på, og andre, som de ikke ville nævne Guds navn over (det vil sige, når de slagtede dem); tilsyneladende blev Guds navn normalt nævnt ved slagtning (6:138). Der var også en skik med at reservere visse dyrs ufødte afkom til mændene i samfundet, idet de forbød deres koner at spise af dem, medmindre afkommet var dødfødt; så deltes de om det (6:139). Tilsyneladende var det - i et af disse ritualer eller dem alle i par at sådanne dyr blev sat til side, for Budbringeren svarer ved at opliste par af får ( $\mathrm{al}$ $\left.d a^{\prime} n\right)$, geder (al-ma'iz), kameler (al-ibl) og køer/okser (al-baqar) og spørger sarkastisk, hvad det lige præcis er, Gud skulle have forbudt: to handyr eller to hundyr, eller det ufødte afkom af to hundyr? Og var de vantro selv til stede, da Gud beordrede dette? Alt dette, siger han, er noget, de urigtigt har tillagt Gud for at lede folk på afveje (6:143f). Endnu engang reagerer han med at fremføre sandheden: der er ikke noget, der er forbudt, bortset fra ådsler, blod, svinekød eller kød, der er indviet til andre end Gud (6:145). Et andet sted fortæller han en advarende lignelse, der som konklusion fremfører disse samme regler (16:112-16).

Heraf forstår vi altså, at de vantro ikke kun holdt kameler, men også får, geder, køer og okser. ”Og kvæget skabte Han til jer. Derfra får I varme (dif') og andre nyttige ting, og I kan spise af det”, som sura 16:5 siger; "I finder også skønhed i det, når I om aftenen genner det ind og om morgenen ud (wa-lakum fîhâ jamâl hîna turîhûna wa-hîna tasrahûna)" (16:6). Her henvises til de kvægflokke, som man stadig dagligt kan se blive drevet til og fra landsbyerne i Mellemøsten i dag, og bemærkningen om, at deres ejere synes, de er smukke, er særligt betydningsfuld: vi befinder os også i et agerbrugssamfund, hvad værdier angår. Når det siges, at ejerne får varme fra deres dyr, henvises der til de varer, som frembringes "[a]f deres uld, pels og hår", der i et andet tekststykke opregnes blandt de goder, som kvæget giver (her fremstilles de vantro dog ikke som dyrenes ejere) (16:80). På dommens dag vil bjergene blive "som kartet uld" 
(101:5). ${ }^{3}$ Folk får besked om ikke at bryde deres pagt med Gud og på den måde opføre sig som en kvinde, der trævler den tråd op, hun har spundet (16:19f), ${ }^{4}$ mens de vantro mindes om, at kvæget giver dem mad og drikke, og at de rider på dem (23:21; 36:71-3, hvor det eksplicit siges, at de ejer dem). De havde også heste, muldyr og æsler, og alle disse red de på (16:8).

At vi befinder os $\mathrm{i}$ et agerbrugssamfund, bekræftes desuden af to lignelser. Den ene handler om en gruppe mennesker, som ejer en have, og som beslutter at indsamle dens frugter den følgende morgen; de vedtager dog at gøre dette uden at sige 'om Gud vil', og i løbet af natten bliver haven ødelagt (tâfa 'alayha tâ'if min rabbikâ); uvidende om dette tager de af sted den følgende morgen, fast besluttet på at forhindre fattige folk $\mathrm{i}$ at komme først til haven, og da de finder den ødelagt, vender de sig angrende til Gud og udtrykker håb om, at Han vil give dem en bedre have end denne (det vil sige $\mathrm{i}$ den kommende verden, 68:17-33). ${ }^{5}$ Som så ofte er moralen, at mennesker må lære at erkende deres egen magtesløshed overfor Gud, som her demonstrerer sin magt ved hjælp af en destruktiv naturkraft. Den anden lignelse, som er meget længere, handler om to mænd, der viser sig at være en troende og en vantro (18:32-44). Gud gav den ene af dem to haver (ikke, som man ville forvente, en have til hver af dem, selvom dette sandsynligvis var sådan, en tidligere version fortaltes). I haverne voksede der vindruer, hver have var omgivet af daddelpalmer (nakhl), og der var en mark (zar') og en kanal (nahr) imellem dem. Begge haver gav en overflod af afgrøder. Vi får ikke at vide, hvad den anden mand fik, men han klarede sig tydeligvis ikke godt, for ejeren af de to haver pralede over for ham med sin overlegne rigdom og magt. Den rige mand øvede også uret ved at gå hen til sin have (nu i ental) og sige:

Jeg tror ikke på, at dette nogensinde vil forgå. Jeg tror ikke på, at Timen kommer (qâ' 'ima); men hvis jeg bliver bragt tilbage til min Herre, så vil jeg sikkert finde, at det er en omvæltning til noget endnu bedre end dette.

Den fattige mand svarede på dette med at spørge ham, om ikke han troede på Gud, som havde skabt ham af en dråbe sæd, selvom den rige mand ikke havde fornægtet Guds eksistens: her som så mange andre steder synes kufr at bestå i ikke at regne Gud med i sine tanker og handlinger snarere end i vantro. Den rige mand havde dog åbenbart øget sit 
hovmod gennem shirk, for den fattige mand fortsatte og bekræftede, at "Han er Gud, min Herre, og jeg sætter ingen ved siden af min Herre!”. Den fattige mand sagde desuden til den rige mand, at sidstnævnte burde have sagt: "Hvad Gud vil! Der findes ingen magt undtagen hos Gud!”, da han gik ind i sin have og tænkte, at den aldrig ville gå til grunde, og at selvom han ikke selv var velsignet med hverken stor rigdom eller mange sønner, ville Herren måske give ham noget bedre end denne have (det vil sige i den kommende verden). Den fattige mand tilføjede, at Gud måske også ville sende en tordenkile mod den rige mands have og forvandle den til sand, eller at Han måske ville få vandet til at løbe bort fra undergrunden, sådan at han aldrig ville kunne finde det igen; og tilsyneladende var det netop, hvad Gud gjorde, for fortsættelsen fortæller os, at den rige mands frugter blev ødelagt (uhîta), og at han gik omkring og vred sine hænder, mens han jamrede: "Gid jeg dog ikke havde sat nogen ved siden af min Herre!". Ingen kunne hjælpe ham bortset fra Gud selv, som er den eneste kilde til beskyttelse.

Dette er sådan, som den arketypiske mushrik portrætteres. Han er her ligesom andre steder i Koranen en mand, der er velsignet med både stor rigdom og mange sønner (68:14; jf. 8:28; 18:46, 57:20), som tror på Gud, men tilskriver Ham partnere kun for at opdage, at de formodede partnere ikke kan eller vil hjælpe ham imod Gud (f.eks. 16:27; 26:92ff; 28:62ff; 46:5). Her ligesom andre steder benægter han (for eksempel) også, at dommens dag vil komme snart eller på noget tidspunkt overhovedet (f.eks. 17:51; 25:11; $34: 3$; 45:32), og han tvivler på genopstandelsen. Ofte afviser de såkaldte mushrikûn helt ideen om kroppens genopstandelse (f.eks. 13:5; 17:49-52, 98; 22:5; 36:78) eller måske hele ideen om efterlivet (f.eks. 6:29, 150; 34:8); i det mindste frygter de i hvert fald ikke regnskabets time (al-hisâb) (78:27). Her er der ingen henvisning til, hvilken form efterlivet vil tage, og ideen om en genomstandelse udelukkes ikke fuldstændigt, men muligheden for at blive straffet i efterlivet benægtes. Som så ofte er det gennem hovmod, at hedningen gør uret: ${ }^{6}$ han er for tilfreds med sig selv, for sikker på sin kun alt for menneskelige magt og frygter Gud for lidt til at lytte til de advarsler, der kommer. "Han regner med, at hans ejendom giver ham evigt liv”, som 104:3 udtrykker det. Så Gud påfører ham ulykker og ødelægger hans have på stort set samme måde, som Han 
ødelagde fortidige folkeslag. Budbringeren advarer gentagne gange sine modstandere om, at en lignende ulykke også snart vil ramme dem.

Den arketypiske mushrik er altså agerbruger. I overensstemmelse med dette bliver de folkeslag, som tidligere profeter blev udsendt til, også fremstillet som agerbrugere. Hûd sagde til sit folk, at Gud havde givet dem kvæg og sønner, haver og kilder (26:133ff) og lovede dem regn til overflod, hvis de ville angre (11:52); Sâlih spurgte sit folk, om de ville blive ved med at være trygge $\mathrm{i}$ deres haver, kilder, marker og daddelpalmer med hylsterblade, der næsten var ved at knække under frugternes vægt (26:146-8). "Har de aldrig draget omkring i landet og set, hvilken ende det tog med dem, der levede før dem?”, spørger Budbringeren og fremhæver, at de folkeslag, der er tale om, gjorde uret, og at det endte galt med dem, selvom "[d]e havde større magt end dem; de pløjede jorden og byggede mere på den, end de har bygget" (wa-athârû 'l-ard wa- 'ammarûhâ akthara mimmâ 'ammarûhâ, 30:9 og kortere, 40:21). Saba' havde to haver og blev pålagt at "Spis jeres Herres underhold", men de vendte sig bort fra Gud, og derfor sendte Han en oversvømmelse, der ødelagde deres haver (34:15f). Folket, som Moses førte ud af Egypten, var også agerbrugere; de lod deres haver, kilder og marker bag sig (44:25f; jf. 26:57-59).

Alle de suraer, der indtil videre er blevet anført, klassificeres som mekkanske, selvom der er uenighed om 6:141 ("Spis af deres frugt, når de bærer, og giv, hvad I har pligt til, når høsten”). ${ }^{7}$ Opdelingen af suraer i mekkanske og medinensiske udspringer selvfølgelig af traditionen, og indtil videre er den ikke blevet skænket nogen opmærksomhed; men læsere, som spekulerer på, om de mange henvisninger til agerbrug kunne være dateret efter Profetens hijra til agerbrugsoasen ved Yathrib, burde vide, at hvad traditionen angår er svaret på dette spørgsmål: Nej.

Vi hører dog også om agerbrug i de suraer, der identificeres som medinensiske. Således sammenligner en lignelse dem, der giver ud efter Guds bud, med et enkelt korn, der skyder syv aks, som hver giver hundrede fold: på samme måde giver Gud en mangfoldig forøgelse af høsten til hvem, Han vil (2:261). Eller de, der giver ud efter Guds bud, er 
som en have på en bakke, der fordobler sit udbytte, når den rammes af voldsom regn og til andre tider klarer sig helt fint med duggen (2:265), hvorimod de, der giver ud for at vise sig for mennesker, er som en klippe dækket af et tyndt lag muld: voldsom regn vasker det bort, og de kan ikke stille noget op (2:264). Det, de vantro giver i denne verden, er som en iskold vind, der ødelægger høsten for de mennesker, der har gjort uret mod sig selv (3:117). Der er mennesker, som taler godt om denne verden, men som i virkeligheden har til hensigt at sprede fordærv og at ødelægge høst og afkom (al-harth wa'l-nasl, 2:205). Og hvem ville ønske at eje en have fuld af daddelpalmer, vindruer og frugter af alle slags med kanaler, der flyder nedenunder, når han er slået af alderdom og svagt afkom, kun for at få den ødelagt af en hvirvelvind med ild, spørger Budbringeren i en sammenligning, jeg ikke helt forstår (2:226). Alt dette er stort set sådan, som man så tidligere, bortset fra at kanalerne i det sidstnævnte tekststykke løber under haverne (antagelig i form af qanâts), sådan som de også gør det i Paradis, frem for imellem dem (i form af kilder og kanaler), som de gør blandt hedningerne. Den ko, som israelitterne blev beordret til at ofre, betragtes som "der ikke er kuet af at vende jorden og vande marken" (lâ dhalûl tuthîru 'l-ard wa-lâ tasqî'l-harth) (2:71), og de attråværdige ting i verden omfatter stadig kvæg og dyrket jord (al-an 'âm wa'l-harth) (3:14).

"Agriculture and vegetation figure prominently in the Qur'ân, reflecting their significance in the environment in which the text was revealed", bemærker Waines i en artikel, der foregriber det meste af det, jeg indtil videre har sagt. ${ }^{8}$ Det er bestemt rigtigt. Hvordan skal vi få dette til at passe med den traditionelle påstand om, at hedningene boede i en gold dal? "The Qur'ân suggests less severe austerity”, bemærker Waines. Hele området kan have været mere frugtbart end det ser ud til, takket være sofistikerede kunstvandingsteknikker, tilføjer Heck: der findes stadig rester af hele nitten eller flere dæmninger i Hijâz. ${ }^{9}$ Men hvis vi ser bort fra, at disse dæmninger helt eller delvist blev bygget efter islams opståen, og at ingen af dem synes at befinde sig i Mekka, løser vi i virkeligheden ikke problemet ved at postulere, at Mekka var frugtbar, for det er Koranen selv, der siger, at Abrahams helligsted befinder sig i en uopdyrket dal (wâdin ghayr dhî $\left.z a r^{\prime}\right)(14: 37)$, ligesom det er Koranen selv, der placerer hedningene i et frugtbart miljø. 
Dette rejser tydeligvis spørgsmålet om, hvorvidt Koranen forestiller sig, at Abrahams helligsted var det sted, hedningene boede. Dette er bestemt ikke umuligt, for det siges, at da Abraham bosatte sine efterkommere ved helligstedet, bad han Gud om at bespise dem med frugt (14:37): måske findes der her en antagelse om, at agerbruget opstod senere. Kan det på den anden side tænkes, at Koranen forestiller sig Abrahams helligsted som forladt af alle undtagen en lille familie af vogtere, der forsørges af pilgrimme og andre besøgende, hvilket antyder, at hedningenes agerbrugssamfund befandt sig et andet sted? Det er også en mulighed. Faktisk synes begge muligheder at have meldt sig for Koranen tidligste læsere, for der findes traditioner, hvori Mekka er usædvanligt frugtbar; sådan var den under Ketura, Jurhum, amalekitterne og Qusayy (men åbenbart ikke i Profetens tid), ${ }^{10}$ og der findes andre traditioner, hvor det er en ørkenhelligdom, indtil Mu âwiya begyndte at grave og bygge dér, hvilket fremkaldte en storm af protester: han havde ingen ret til at anlægge haver på et sted, som Gud selv havde beskrevet som blottet for dyrkning; Mekka burde vedblive med at være et sted med vidstrakte, ubebyggede områder, som var tilgængelige for alle; et sted, hvor pilgrimmene kunne rejse deres telte, sådan som de havde gjort i fortiden, ikke et sted med byer og befæstede palæer (mada'in wa-qusûr). ${ }^{11}$ Men Koranen siger også, at Gud havde etableret et helligsted, hvor man kunne være i sikkerhed (haraman aminan), imens mennesker, der boede omkring de vantro, blev bortført (29:67), og når folk afviser vejledning, fordi de ville blive bortført fra deres jord, hvis de fulgte den, er gensvaret: "Har Vi ikke gjort dem indflydelsesrige på et sikkert, fredhelligt (haraman âminan) område, hvortil der bliver bragt alle slags frugter som underhold fra Os?” (28:57). Dette kunne forstås sådan, at de vantro virkelig boede på deres helligsted, men også at de gjorde dette uden at udvikle det i agerbrugsmæssig forstand: frugterne kom udefra. ${ }^{12}$ Dette var den løsning, som traditionen besluttede sig for. Det var som svar på Abrahams bøn, at Gud fastsatte de to handelsrejser, gennem hvilke Han udfriede Quraysh fra sult og frygt, ifølge nogle; ${ }^{13}$ eller det var som svar på Abrahams bøn, at Han flyttede Tâ'if fra Syrien til Arabien, som vi også får at vide; ${ }^{14}$ frugterne kom fra de nærliggende byer og landsbyer, som mange siger; ${ }^{15}$ eller det var ved at få de nærliggende byer og landsbyer til at komme med forsyninger til Mekka, at Gud gjorde Quraysh i stand til at holde op med at tage på deres to handelsrejser, sådan som 
tilhængere af det synspunkt, at Mekkas handelsvirksomhed ophørte et stykke tid inden islams opståen, erklærede. ${ }^{16}$

Hvordan håndterer eksegeterne de vers, hvori polyteisterne implicit eller eksplicit beskrives som agerbrugere? Mærkeligt nok synes de at ignorere problemet. Det er faktisk kun, hvis man interesserer sig for åbenbaringens historiske kontekst, at man lægger mærke til, at de eksempler, der benyttes til at overbevise de vantro, er besynderlige: for enhver anden læser vil bogen fremstå, som om den anfører pointer, der er universelt forståelige og har evig gyldighed. Men de tidlige eksegeter interesserede sig faktisk for den historiske kontekst. Det er også rigtigt, at den eksegetiske litteratur er uhyre omfattende, og at det derfor er umuligt at udtale sig med fuldstændig sikkerhed om, hvad der findes eller ikke findes i den, i særdeleshed når der er et så stort antal koranvers involveret. Det er vanskeligt at forestille sig, at problemet ikke er blevet bemærket. Men en undersøgelse af et rimeligt uddrag af den eksegetiske litteratur, der omhandler de mest åbenlyst problematiske tekststykker - dem, der fremstiller de vantro som olivendyrkere gav intet resultat.

Man ville forvente, at det svar, eksegeterne kom frem til, er, at de tekststykker, der omhandler agerbrug, refererer til steder uden for Mekka og frem for alt til Tâ'if, hvor indbyggerne i Mekka ejede haver. Hvilken anden forklaring kunne der være? Det løser også problemet indtil et vist punkt, for daddelpalmer, granatæbler og vindruer passer alle uden problemer til Tâ'if. Men korn og oliven er et større problem. Efter erobringerne, da Mu'âwiya og andre velhavende Qurashî'er i massivt omfang begyndte at udvikle Hijâz i agerbrugsmæssig retning, blev der korn høstet dér i stor stil, ${ }^{17}$ og måske kunne man argumentere for, at det også blev dyrket dér før islams opståen. Men traditionen associerer altid korn med Syrien. ${ }^{18}$ På baggrund af den viden, vi har, kan der efter erobringerne godt have været forsøg på også at dyrke oliven i Hijâz; ${ }^{19}$ men hvis det var tilfældet, ville de af indlysende grunde ikke have haft held med sig: i sin dyrkede form er oliventræet (Olea europaeana) tilpasset et middelhavsklima. Det vokser ganske vist vildt i Arabiens bjergrige skov- og buskområder, heriblandt Tâeif-regionen, men den vilde oliven er en del af vegetationen, der forbinder Arabien med Afrika snarere end med 
Middelhavsområdet, i form af underarten africana.$^{20}$ Set fra et arabisk synspunkt har den dyrkede oliven den ulempe, at den kræver vinterkulde for at kunne blomstre og bære frugt. $^{21}$ Den kunne ikke have givet megen høst i hverken Mekka eller Medina, ${ }^{22}$ og selvom Tâ'if ser mere lovende ud, er det i den nordlige oase Jawf (tidligere Dûmat alJandal), at olivendyrkning i moderne tider er blevet foretaget med held. ${ }^{23}$ Kilderne, der handler om Arabien umiddelbart før islams opståen, beskriver altid oliven som noget, der kommer fra Syrien. ${ }^{24}$ Når Koranen prøver at overbevise folk med eksempler, hvori kornog olivendyrkning indgår, er den eneste udvej altså - hvis vi vil holde os til traditionen at der henvises til landsbyer i Syrien, som indbyggerne i Mekka kom igennem på deres forretningsrejser og/eller til besiddelser, de havde erhvervet sig dér, og som de selv dyrkede sådanne afgrøder på.

At antage, at de pågældende tekststykker henviser til Tâ'if og Syrien løser dog ikke problemet fuldstændigt. For det første er der stadig spørgsmålet om, hvordan en uopdyrket dal med én enkelt kilde kunne opretholde livet hos de får, geder, køer, okser, kameler, muldyr, æsler og heste, som hedningene tilskrives i Koranen, eller om hvordan der dagligt kunne findes græsning til dem uden for Mekka. For det andet er der noget konstrueret ved den læsning. En prædikant vil normalt forsøge at komme igennem til folk ved at tale til dem om de ting, der betyder mest for dem, og traditionen er helt klar $\mathrm{i}$ spørgsmålet om, at ligegyldigt hvad de førislamiske Quraysh i øvrigt foretog sig, så var de først og fremmest handelsmænd. Man ville ikke forsøge at omvende børsmæglere på Manhattan ved at spille på deres frygt for, at der gik noget galt med deres perifere forretninger eller ved at tale om vidunderne ved nogle varer, som de havde set på deres forretningsrejser; man ville derimod tale til dem om børskrak, lavkonjunkturer, arbejdsløshed, økonomisk ruin og den ultimative værdiløshed ved et liv, der er viet til stræben efter rigdomme. Mutatis mutandis er dette tydeligvis også det, den koranske prædikant gjorde. Han henvendte sig til folk, der levede af, hvad de kunne dyrke i deres haver og på deres marker, og det gør han med en rigdom af lokale detaljer, som viser, at han selv er godt hjemme i miljøet: der var haver med espalierer (til vinstokke) og haver uden (ma'rûshât wa-ghayr ma'rûshât, 6:141); palmer kunne være enkeltstammede eller dobbeltstammede (13:4); ${ }^{25}$ jorder, vingårde, palmetræer og marker, der lå ved siden af 
hinanden, kunne måske alle vandes ved hjælp af en enkelt kilde (13:4); haver var somme tider - måske mest typisk - omgivet af palmetræer og adskilt af tilsåede marker og kanaler (18:32f); og af alle de ulykker, der kunne tænkes at ramme et jordlod, var det værste mareridt, at vandet skulle forsvinde ned under jorden og ikke længere være tilgængeligt (18:41). Der fandtes et stort og rigt ordforråd, som havde med daddelpalmen at gøre, og også udtryk for kløver, kornets blade eller stængler, stubbe, haver med tæt sammenplantede træer (jannât alfâf) (78:16) og mange andre ting. ${ }^{26}$

\section{Rejser til lands og til vands}

Agerbrug var dog ikke den eneste økonomiske aktivitet, som hedningene beskæftigede sig med. De rejste også både til lands og til vands, muligvis for at handle. Der findes en dunkel henvisning til en "journey (rihla) in winter and journey in summer" i 106:2 og en ligeså dunkel henvisning til folk, som har gjort uret ved at bede Gud om, at intervallerne mellem deres rejser måtte blive længere (rabbanâ bâ 'id bayna asfârinâ, 34:19). Om disse rejser blev foretaget over land eller vand, er ikke til at sige. Men en af de fordele, kvæget havde, var, at "[d]e bærer jeres byrder til et land, som I ellers kun ville nå med besvær." (16:7). Man kommer ligeledes til at tænke på rejser over land, når vi får at vide, at Gud sørgede for "huse af kvægets hud, lette at håndtere den dag, hvor I bryder op, og den dag, hvor I gør holdt” (16:80), selvom de vantro antageligt også sov i telte, når de ankom til deres bestemmelsessted over havet; og Koranen spørger ofte de vantro, om ikke de har været rundt i landet (a-wa-lam yasîru fíl-ard) og set ruinerne efter forgangne nationer, eller også pålægger den dem at gøre dette $(16: 36 ; 27: 69 ; 30: 9,42 ; 40: 82 ; 47: 10$; jf. 22:46).

Henvisninger til det at sejle og til havet er både talrige og levende (som det tidligere er blevet bemærket, antyder dette, at Profeten havde været på havet). ${ }^{27}$ De folk, der bliver talt til, rider ikke kun på kvæg, men 'rider' også på skibe $(23: 22 ; 40: 80 ; 43: 12)$, og de ledtes af stjernerne i mørket både til lands og til vands (6:97; jf. også 10:22). De mindes om, at Gud sendte vindene "for at skibene kan sejle på Hans befaling, og I kan stræbe efter noget af Hans gunst" (30:46). "[D]u kan se skibene pløje sig igennem det, for at I kan stræbe efter Hans overflod" (16:14; 35:12); "Det er jeres Herre, der driver skibene af 
sted for jer på havet, så I kan stræbe efter noget af Hans gunst” (17:66), som andre versioner siger (jf. også 22:65; 31:31). Når de folk, der tales til, blev fanget i storme på havet, påkaldte de udelukkende Gud, men når de nåede op på landjorden, tilskrev de Ham partnere (10:22ff; 29:65; 31:32); og i en sura, der klassificeres som medinensisk, sammenlignes de vantro med mennesker på rejser både til lands og til vands: deres gerninger er ligesom de luftspejlinger i ørkenen, som en mand, der er ved at dø af tørst, tror er vand, eller som skyggerne på det mørke ocean, hvor bølger tårner sig op over andre bølger og skyer tårner sig op over hinanden, så man til sidst næsten ikke kan se en hånd for $\operatorname{sig}(24: 39 f)$.

Nogle af disse rejser kunne have haft handelsmæssige formål. "At stræbe efter noget af Guds gunst" (det vil sige at forsøge at finde noget at leve af) synes i nogle tekststykker bestemt at være et udtryk for handel (jf. 2:198; 62:10, som diskuteres nedenfor). Men modsat det indtryk, som sekundærlitteraturen jævnligt giver, forbinder Koranen ingen af disse rejser med handel. ${ }^{28}$ Nogle af bevægelserne rundt i landet skal sandsynligvis forbindes med græsning, og rejser til vands synes somme tider at blive foretaget på grund af fiskeri. Således er der et tekststykke, der siger, at

Han er den, der har sat havet i tjeneste, for at I derfra kan få frisk kød (li-ta'kulu minhu lahman tariyyan) at spise og deraf uddrage smykker til at tage på jer. (16:14)

Vi skal altså betragte hedningene som mennesker, der spiser fisk og smykker sig med muslingeskaller eller måske (som eksegeterne foreslår) med perler. Andetsteds beskrives samfundet som ét, der både benytter ferskvands- og saltvandsprodukter:

De to have er ikke ens. Det ene er frisk og sødt, behageligt at drikke (furât), og det andet er salt og bittert. Fra hvert får I frisk kød at spise og kan uddrage smykker til at tage på jer. Man kan se skibene pløje dem, for at I kan stræbe efter Hans gunst. $(35: 12)$

Det er yderst overraskende, at indbyggerne i Mekka skulle have været fiskere, for slet ikke at tale om, at de skulle have spist ferskvandsfisk, selv hvis man antager, at fiskene var blevet konserveret. Hvilken flod eller sø har dette tekststykke i tankerne? Der findes 
en lignelse om fiskere i Koranen. "Spørg dem om den by, der lå ved havet! Da de begik overtrædelser på sabbatten!”, begynder den (7:163). Men man ville tro, at denne historie handlede om jøder, og at den måske også var henvendt til dem, selvom suraen klassificeres som mekkansk.

\section{Handel}

Den eneste eksplicitte henvisning til handel i de mekkanske suraer findes i form af formaninger om ikke at snyde med vægt og mål. Gud havde skabt vægten "for at I ikke skulle være overmodige, når I vejer. Indstil vægten rigtigt, og giv ikke for lidt, når I vejer!” (55:7f), siger et tekststykke og bevæger sig derfra videre til, at Gud skaber daddelpalmen, kornet og de sødtduftende planter (al-rayhân). ”Giv fuldt mål, når I måler op, og vej med en ordentlig vægt!" (17:35); "Giv fuld vægt og mål i al retfærdighed!" (6:152). Shu ayb siger nogenlunde det samme (7:85; 11:84f; 26:181), og de som kræver fuldt mål til sig selv, samtidig med at de giver for lidt til andre, bliver skarpt fordømt (83:1-9). Man ville tro, at disse formaninger henviser til interne udvekslinger snarere end til handel med udenforstående for slet ikke at tale om langdistancehandel. Der findes lignende fordømmelser af snyderi med mål og vægt i Det Gamle Testamente, som udspiller sig i et agerbrugsmiljø.

Den agerbrugsmæssige atmosfære, som findes i de mekkanske suraer, er så meget desto mærkeligere i betragtning af, at Profetens sprog fra begyndelsen er overgydt med handelsmetaforer, specielt $\mathrm{i}$ forbindelse med belønning og straf. ${ }^{29}$ Mennesker betragtes som nogen, der har et regnskab hos Gud; Han indfører deres handlinger enten på debeteller kreditsiden i en bog eller hovedbog (kitâb, imâm), som både er klar (mubîn) og omhyggelig: der er intet, der udelades $(10: 61 ; 18: 49 ; 21: 94 ; 34: 3 ; 36: 12 ; 45: 28 f ; 78: 29$; jf. kitâb hafìz i 50:4). Hver eneste sjæl ses som pantsat (rahîna) hos Gud, det vil sige som sikkerhed for den gæld, den har akkumuleret (74:38, jf. 52:21), ${ }^{30}$ og handlinger beskrives også som forskud, der gives til Gud (aslafat, aslaftum), som vil indløse dem på dommens dag $(10: 30 ;$ 69:24). Når regnskabets time (yawm al-hisâb) kommer, vil hvert eneste individ blive konfronteret med sin egen personlige regnskabsbog, eller hver eneste nation vil blive konfronteret med sin optegnelse (45:28f). Retfærdige individer vil få overrakt 
deres bog i højre hånd, syndere i den venstre eller bagfra (på den ikke iøjnefaldende måde, som benyttes af diskrete kreditorer) (69:19, 25; 84:7f, 10f; jf. også 56:8f), ${ }^{31}$ og alle vil blive bedt om at læse deres vidnesbyrd højt (69:19; 17:13f: iqra'kitâbaka); det tages for givet, at folk kan læse. I en alternativ metafor blive sjælene vejet, og mennesker, hvis handlinger vejer tungt, vil få fremgang, mens de, hvis gerninger er lette på vægten, vil blive tabere (23:102f; 7:8f; 101:5). Til forskel fra hedningene anvender Gud retfærdige vægtskåle (21:47) og giver fuldt mål både af belønning og straf; hver sjæl vil få, hvad den har fortjent. ${ }^{32}$ Bortset fra disse ofte benyttede metaforer fraråder et enkelt tekststykke, at man sælger sin pagt med Gud for en lav pris (16:95; sammenlign med det udtryk, der bruges om det bogstavelige salg i historien om Josef, 12:20), og et andet taler om at købe indholdsløse historier (31:6), men metaforer, der har med det at købe og sælge at gøre, er meget mere almindelige i de suraer, der klassificeres som medinensiske. ${ }^{33}$

I princippet kunne disse metaforer simpelthen have været en del af det nedarvede religiøse sprog, for de fleste af dem bevidnes før islams opståen, i nogle tilfælde endda $\mathrm{i}$ arabisk digtekunst. ${ }^{34}$ Men brugen af dem i de mekkanske suraer er så konsekvent og levende, at man ville formode, at de afspejler almindeligt udbredte tilstande, eller i det mindste en handelsmæssig fortid, der ikke ligger særligt langt tilbage. ${ }^{35}$ De handelstransaktioner, der afspejles i dem, kunne dog have været helt eller overvejende interne.

\section{Det hedenske samfund: sammendrag}

Alt $\mathrm{i}$ alt fremstiller de tekststykker fra Koranen, der er henvendt til eller beskæftiger sig med hedningene, en blandet økonomi, hvor dyrkningen af korn, vindruer, oliven og daddelpalmer blev kombineret med opdræt af får, geder, kameler, køer, okser og andre dyr, og også med maritim aktivitet, som i det mindste somme tider var fiskeri. Samfundet var tilstrækkeligt differentieret til at der fandt interne udvekslinger af varer sted, og derudover kan der også have været tale om ekstern handel, men ikke i en størrelsesorden, der gjorde det vigtigt nok til, at en prædikant ved hjælp af det emne ville forsøge at røre ved hedningenes dybeste følelser. Gud beskrives aldrig som én, der straffer folk ved at ødelægge handelsforetagender, tillade at karavaner plyndres eller begraves i sandstorme, 
og der findes ingen lignelser om handel i bogen. Alligevel vidner metaforerne om, at der fandtes et veludviklet system med hensyn til at opbevare skrevne optegnelser, hvilket antyder, at der til trods for det landlige miljø var tale om et relativt sofistikeret samfund. Det forudsættes, at størstedelen af befolkningen kan læse.

\section{De troendes samfund}

Vi kan nu vende os imod de tekststykker, der regulerer de troendes opførsel på en måde, som viser, at de er kommet så langt som til at danne et samfund - om end måske endnu ikke et politisk uafhængigt et af slagsen. Vi er allerede stødt på nogle af disse tekststykker: de fremstillede de troende som agerbrugere ligesom hedningene. Det er dog ikke dem alle, der gør dette. En god del af dem - næsten alle klassificeret som medinensiske - beskriver de troende som handelsmænd.

" I, som tror! I skal ikke fortære jeres formue ved falskhed indbyrdes, men det skal være handel (tijâra) til jeres gensidige tilfredshed!" forkynder 4:29: handel var en god ting. Bortset fra det skulle de troende huske på, at intet kunne være vigtigere end Gud og Hans Budbringer:

Sig: "Hvis jeres fædre og jeres sønner, jeres brødre, jeres hustruer og jeres nærmeste; hvis de rigdomme, I har vundet jer, og handelsvarer, som I frygter at brænde inde med (amwâl iqtaraftumûhâ wa-tijâra takhshawna kasâdahâ), og boliger, som I er tilfredse med - hvis alt dette er jer kærere end Gud og Hans udsending og kampen for Guds sag, så vent, til Gud kommer med sin befaling!" $(9: 24)$

De forbilledlige troende var mænd, "hvis opmærksomhed hverken handel eller salg (altijâra wa'l-bay') afleder fra at tænke på Gud, holde bøn og give almisse, af frygt for en dag, hvor hjerte og blik går omkuld" (24:37). Men det var mere, end man kunne sige om de fleste af dem:

I, der tror! Når der kaldes til bønnen på forsamlingens dag, så bestræb jer på at ihukomme Gud, og lad handel være handel (al-bay)! Det er det bedste for jer, hvis I blot vidste det! Når så bønnen er til ende, skal I sprede jer i landet og stræbe efter Guds gunst og tænke meget på Gud! Måske vil det gå jer godt. Når de øjner handel (tijâra) eller underholdning, løber de derhen og lader dig stå tilbage. Sig: "Hvad 
der findes hos Gud, er bedre end underholdning og handel." Gud er den bedste forsørger. $(62: 9-11)$

Et andet sted hører vi om troende "travelling in the land, seeking of God's bounty" (73:20), antageligt som handelsmænd. ${ }^{36}$ "I begår ingen synd ved at tragte efter nådegaver fra jeres Herre," som vi får at vide i bestemmelserne for pilgrimsfærden (2:198): her kunne man ligeledes læse tekststykket, som om det henviste til handel (hvilket også er den måde, eksegeterne læser det på), eftersom der ikke kan have været andre måder at skaffe sig en indkomst på under pilgrimsfærden. Somme tider blev der deponeret guld hos Bogens Folk: nogle af dem ville troligt returnere en hel qintâr, som de var blevet betroet, mens andre ville nægte at returnere en dînâr, hvis ikke man vedholdt sit krav, idet de hævdede, at de ikke havde moralske forpligtelser over for vantro (det vil sige ikke-jøder) (3:75).

Vi lades således ikke i den mindste smule tvivl om, at de troende beskæftigede sig med, ja endda var meget optaget af, handel. I overensstemmelse med dette findes der en hel del bestemmelser, der angår handelsmæssige transaktioner. Gud havde tilladt det at købe og sælge, men Han havde forbudt åger (2:257f), og selvom de troende var berettiget til deres kapitalsummer, skulle de være milde over for deres skyldnere og frygte den dag, hvor hver sjæl ville blive betalt det, den havde gjort sig fortjent til (2:279-281). Når folk lånte penge, blev det anbefalet, at de fik en skriver til at dokumentere aftalen ifølge skyldnerens diktat eller ifølge diktat fra én, der repræsenterede ham, og fik den bevidnet af to mænd eller af en mand og to kvinder; det var bedst, at alle handelsmæssige transaktioner var nedskrevne, med mindre de blev afsluttet på stedet, og alle skulle de bevidnes, hvad enten de var nedskrevne eller ej (2:282). Men hvis de troende var på rejse og ikke kunne finde en skriver, ville et pant være godt nok (i stedet for et dokument). Ting, der blev deponeret på kredit, skulle troligt returneres (2:283). Til forskel fra høstritualernes bestemmelser og de formaninger, der angår ærlighed i forhold til mål og vægt, opstilles disse regler uden polemik imod de hedenske måder at gøre tingene på.

Der findes også meget handelsmæssigt billedsprog i de medinensiske suraer, og det har mest med det at købe og sælge snarere end med regnskabsførelse at gøre. ${ }^{37}$ Meget af dette 
bruges imod jøder og mushrikûn, som siges at sælge Guds tegn eller pagt for en lav pris, eller som advares imod at gøre dette $(2: 41 ; 3: 187 ; 5: 44 ; 9: 9$; jf. den mekkanske 16:95), eller roses for ikke at gøre dette (3:199), eller som skjuler åbenbaringer eller fabrikerer dem for at kunne sælge dem til en lav pris $(2: 79,174)$, eller som sælger deres tro eller deres sjæle for en sådan pris $(2: 90,102 ; 3: 77)$, eller køber dette liv med det næste (2:86), imens de og andre køber vildfarelse og usandhed for vejledning, eller vantro for troens pris $(2: 16 ; 3: 177 ; 4: 44$; jf. også 5:106). Som modsætning hertil findes der mennesker, som sælger deres sjæle for at opnaa Guds vilje (2:207), især de der giver deres liv og ejendom til sagen:

Lad dem, der vil sælge det jordiske liv for det hinsidige, kæmpe for Guds sag (4:74); Gud har købt de troendes liv og ejendom af dem mod, at de vil få Haven idet de kæmper for Guds sag, dræber, og selv bliver dræbt [...] Så glæd jer over den handel, som I har sluttet med Ham! (9:111).

Eller igen:

I, der tror! Skal jeg udpege en handel (tijâra) for jer, som vil frelse jer fra en pinefuld straf? I tror på Gud og Hans udsending og kæmper for Hans sag med jeres ejendom og jeres liv. Det er det bedste for jer, hvis I blot vidste det.(61:101f)

At vie sin rigdom og/eller sit liv til Ham fremstilles nu som et lån (qard], som Gud til overflod vil betale tilbage:

De mænd og kvinder, der giver almisse og har givet Gud et smukt lån, vil få det mangefold igen. De har en gavmild løn i vente. $\left(57: 18 ; 73: 20^{38}\right)$

Kæmp for Guds sag! I skal vide, at Gud hører alt og ved alt. Hvem vil give Gud et smukt lån, så Han kan gøre det mange gange større for ham? (2:244f)

Hvem vil give Gud et smukt lån, som Han vil betale ham mangefold tilbage? (57:11;64:17).

Alt hvad I giver bort for Guds sag, vil blive betalt jer fuldt tilbage. I vil ikke blive gjort uret $(8: 60)$

Troende, som forholder sig afventende, beskrives som mennesker, der gør dårlige forretninger med Gud: de har købt vildfarelse for vejledning, "handelen gav intet 
udbytte" (fa-mâ rabihat tijâratuhum) (2:16). Derimod: "De, der læser op af Guds skrift og holder bøn og giver bort af det, som Vi har forsørget dem med, hemmeligt eller åbenlyst, kan håbe på en handel, der ikke vil blive til intet (tijâratan lan tabûra)" $(35: 29){ }^{39}$

\section{Sammenfatning}

Koranen er temmelig rig på detaljer om både hedningenes og de troendes levebrød, men resultatet er problematisk. Bogen beskriver de to parter som medlemmer af et samfund, der i overvældende grad er baseret på agerbrug, mens den også skildrer, hvordan de troende skaber deres eget samfund, hvori handel var en fremtrædende beskæftigelse. Mere groft sagt beskriver den hedningene som agerbrugere og de troende som handelsmænd: situationen er den omvendte af, hvad man forventer. Det burde ikke være alt for vanskeligt at bringe det billede af de troendes samfund, som angives i Koranen, i overensstemmelse med billedet af Profetens Medina, sådan som det beskrives i andre kilder, men bogens beskrivelse af et samfund, der deltes af hedninger og de troende, kan næppe siges at pege på Mekka, sådan som vi kender byen fra traditionen. Hvordan kommer vi videre herfra? Jeg ønsker ikke at bebyrde denne artikel med gisninger og overlader hermed spørgsmålet til læseren.

Jeg vil gerne takke Michael Cook for kommentarer til denne artikel.

Patricia Crone er professor i islamisk historie, Institute for Advanced Study, Princeton, USA.

(Oversat af Juliane Wammen) 
${ }^{1}$ Koranhenvisningerne stammer fra den foreløbige version af Ellen Wulffs Koranoversættelse, juni 2006.

2 Se Watt, W.M., 1971: "Belief in a 'High God' in Pre-Islamic Mecca", Journal of Semitic Studies 16; Hawting, G.R., 1999: The Idea of Idolatry and the Emergence of Islam, Cambridge University Press, Cambridge

3 "Kartet uld" er ogsaa hvad man finder i Yusuf Ali's oversaettelse; Arberry's har "like plucked wool-tufts".

${ }^{4}$ Eller som den kvinde, der trævlede den tråd, hun spandt, op (en læsning, der vækker mindelser om Penelope).

${ }^{5}$ Lignelsen menes at henvise til første afgrøde (Benthall, J., 2002: "Firstfruits in the Quran”, in: Sacrifice in Religious Experience, A.I. Baumgarten (ed.), Leiden (med henvisning til Décobert)). Han diskuterer ikke 6:136.

${ }^{6}$ Jf. McAuliffe, J.D. (ed.), 2001: Encyclopaedia of the Qur'ân, Leiden, se under 'arrogance' (Nasr Abu Zayd).

${ }^{7}$ Problemet var forholdet mellem den regel, der blev pålagt i dette vers, og zakât, der pålagdes i Medina, ikke fremstillingen af de troede som agerbrugere. Se for eksempel Fakhr al-Din al-Râzî, 1413: al-Tafsîr alkabîr, Tehran, xiii, 213.

${ }^{8}$ D. Waines: 'Agriculture,' i McAuliffe op. cit. 40.

${ }^{9}$ Heck, G.W., 2003: "Arabia Without Spices': an Alternate Hypothesis", Journal of the American Oriental Society 123, 566.

${ }^{10}$ Se de kilder, der anføres i Crone, P., 1987: Meccan Trade and the Rise of Islam, Oxford and Princeton, 198 , note 134.

${ }^{11}$ Al-Kalbî i al-Bakrî, 1858: Mu'jam mâ ista jam, F. Wüstenfeld (ed.), Leipzig; Kister, M.J., 1972: "Some Reports Concerning Mecca from Jâhiliyya to Islam", Journal of the Economic and Social History of the Orient 15, 86ff; begge anført i Crone op. cit., 197f (hvor qusûr oversættes med 'palaces'). Angående Mu'âwiyas agerbrugsudvikling af regionen, se også nedenfor, note 17.

12 Den alternative læsning ville være, at de simpelthen havde søgt tilflugt på helligstedet under en eller anden krise, da de risikerede at blive 'bortført' fra den jord, de normalt levede og arbejdede på.

${ }^{13}$ Nævnes i al-Zamakhsharî, 1948: al-Kashshâf, Beirut, iv, 803, ad 106:4, hvor de to rejser nævnes (uden at de beskrives som havende noget som helst med handel at gøre, jf. nedenfor, note 28).

${ }^{14}$ Således f.eks. al-Tabarî, 1988: J âmi'al-bayân, Beirut, viii, 235, ad 14:37; jf. også Kister, M.J., 1979; "Some Reports Concerning Tâ'if", Jerusalem Studies in Arabic and Islam, i, note 77.

${ }^{15}$ Således f.eks. Tabarî, al-Mâwardî, Fakhr al-Dîn al-Râzî ad 14:37.

${ }^{16}$ Muqâtil b. Sulaymân, 1979: Tafsîr, ‘A.M. Shihâta (ed.), Cairo, iv, 861f, ad sura 106; al-Kalbî i Ibn Habîb, 1964: al-Munammaq, Hyderabad, 262f; jf. Crone op. cit. $205 f f$.

17 Angående Mu âwiyas gravning af brønde og kanaler og anlæg af haver i Mekka (angiveligt som den første), se Kister op. cit., 89f; jf. også hans dæmning ved Tâ'if (Miles, G.C., 1948: "Early Islamic Inscriptions Near Tâ'if in the Hijâz", Journal of Near Eastern Studies 7) og de dæmninger, der nævnes i Heck op. cit., 566. Angående Mu'âwiyas agerbrugsvirksomhed i Medina i Hijâz og de spændinger, det forårsagede, se Kister, M.J., 1977: "The Battle of the Harra: some Socio-Economic Aspects”, i M. RosenAyalon (ed.): Studies in Memory of Gaston Wiet, Jerusalem, 38ff, og ovenfor, note 9; ang. andre Qurashî'er, se Heck op. cit., 565, som uforvarende formoder, at deres aktiviteter var førislamiske. Heck anfører også den ubestrideligt førislamiske Abû Tâlib som et eksempel på en klasse af iværksættere, som var "sufficiently wealthy that no external investment capital was necessary to underwrite their productive ventures", og hævder, at han var "among the Makkan wheat growers who sold their own produce", samt bemærker at "in addition to being a major grain broker, Abû Tâlib was a perfume merchant" (op. cit. 561, 571). Angående alt dette henviser han sin læser til Ibn Qutayba, som blot siger, at "Abû Tâlib solgte parfume, og måske/nogle gange (rubbamâ) solgte han hvede (al-burr)." (Ibn Qutayba, 1850: al-Ma'ârif, F. Wüstenfeld (ed.), Leiden, 283; Th. 'Ukâsha (ed.), 1969, Cairo, 575; M.I 'A. al-Sâwî (ed.), 1970, Beirut, 249; i den tilsvarende version, som Ibn Rusta skriver den, er burr erstattet af lubân, jf. Crone op. cit., 53n). Der findes ingen dokumentation for, at han var mellemmand for handlen med korn (i modsætning til blot at være handelsmand), at han var en større en af slagsen, at han dyrkede sine egne afgrøder, eller at han var rig nok til at klare sig uden ekstern investeringskapital.

${ }_{18}$ Jf. Crone op. cit., 98, 104, 139-41, 150, 160. Kornet kommer også fra Syrien i alle de eksempler, der anføres hos Heck op. cit., 573 (ang. det om 'Abdallâh b. Jud'ân, hvor han ikke specificerer dets 
oprindelsessted, se Crone op. cit., 104). Heck foreslår ikke desto mindre, at indbyggerne i Mekka både kunne importere og eksportere sådanne ting (idet de havde dyrket dem ved Tâ'if og andre steder), afhængigt af "the basic functioning of the free market economics", hvor han fremfører handelsmønstrene mellem nutidens Michigan og Wisconsin som eksempel (op. cit. 573). Men hvis man lader ude af betragtning, at vi aldrig hører om, at indbyggerne i Mekka eksporterer sådanne ting, var de ikke en del af en moderne kapitalistisk økonomi baseret på hurtig distribution af oplysninger og varer, lave transportomkostninger og en befolkning, der køber sine varer (deriblandt fødevarer) på det åbne marked.

19 Mange agerbrugsmæssige eksperimenter i erobringernes kølvand forudsættes af den spredning af afgrøder, som A.M. Watson har studeret i Agricultural Innovation in the Early Islamic World, 1983, Cambridge.

${ }^{20}$ Ghazanfar, S.A. \& Fisher, M. (eds.), 1990: Vegetation of the Arabian Peninsula, Dordrecht, 69, 91-3, 130; kortere desuden Miller, A.G. \& Cope, T., 1996: Flora of the Arabian Peninsula and Socotra, vol. i, Edinburgh, 20f, 26. Dette er tydeligvis den plante, som araberne kendte som 'utum eller 'bjergoliven' (zaytûn jabalî), der voksede i Sharât og (i en højere udgave) i Oman; den havde sorte frugter ligesom vindruer, som ikke var spiselige, eller også satte den ikke frugt, men blev anvendt til medicinske formål og som materiale til tandstikkere (Abû Hanifâ al-Dînawarî, 1973: Kit âb al-nabat, s-y, ed. M. Hamîdallâh, Cairo, nos. 574, 686, se under 'shahs' og ' utûm.' Sammenlign distributionen i Ghazanfar \& Fisher op. cit., 91-3, 130 med en henvisning til den medicinske brug på s. 250).

${ }^{21}$ To uger med temperaturer under $14^{\circ} \mathrm{C}\left(57^{\circ} \mathrm{F}\right)$ er nødvendigt for de fleste dyrkede afgrøder, hvis man ønsker at fremkalde blomstring (Shaffer, B \& Andersen, P.C. (eds.), 1994: Handbook of Environmental Physiology og Fruit Crops, Boca Raton, Fl., i, 171), men koldere temperaturer er nødvendige for de afgrøder, der er umagen værd. FAO taler om en hviletilstand i omkring to måneder, hvor temperaturen skal være lavere end $10^{\circ} \mathrm{C}\left(50^{\circ} \mathrm{F}\right)$ (www.fao.org/af/agl/aglw/cropwater/olive.stm); et californisk firma definerer den bedste vintertemperatur som liggende omkring $-2,8$ til $3,9^{\circ} \mathrm{C}\left(25\right.$ til $\left.27^{\circ} \mathrm{F}\right)$, mens den kun sjældent må komme under $-6,1^{\circ} \mathrm{C}\left(21^{\circ} \mathrm{F}\right)$. Områder, der normalt har vintertemperaturer, som ligger oppe på $12,2^{\circ} \mathrm{C}$ $\left(54^{\circ} \mathrm{F}\right)$ med sjælden frost og som næsten aldrig kommer ned på $-2,2^{\circ} \mathrm{C}\left(28^{\circ} \mathrm{F}\right)$, beskrives som uegnede eller marginale i forhold til kommercielle olivenlunde ('Peaceful Valley Farm Supply' på www.groworganic.com/d/d3_205.html).

${ }^{22}$ De laveste temperaturer, der blev registreret i Mekka og Medina gennem de elleve år mellem 1985-1995, var henholdsvis $10^{\circ} \mathrm{C}\left(50^{\circ} \mathrm{F}\right)$ og $3^{\circ} \mathrm{C}\left(37^{\circ} \mathrm{F}\right)$. (De højeste temperaturer var $49,5^{\circ} \mathrm{C}\left(121^{\circ} \mathrm{F}\right)$ og $47,5^{\circ} \mathrm{C}$ $\left(118^{\circ} \mathrm{F}\right)$ med en middeltemperatur på $30,8^{\circ} \mathrm{C}\left(87^{\circ} \mathrm{F}\right)$ og $27,9^{\circ} \mathrm{C}\left(82^{\circ} \mathrm{F}\right)$.) Se kurven hos Ghazanfar \& Fisher op. cit., 22.

${ }^{23}$ Den laveste temperatur i Tâ'if og Jawf (Jouf) i den periode, der nævnes i den foregående note, var henholdsvis $-2^{\circ} \mathrm{C}\left(30^{\circ} \mathrm{F}\right)$ og $-7,0^{\circ} \mathrm{C}\left(19^{\circ} \mathrm{F}\right)$. (De højeste temperaturer var $39,5^{\circ} \mathrm{C}\left(103^{\circ} \mathrm{F}\right)$ og $46^{\circ} \mathrm{C}\left(117^{\circ} \mathrm{F}\right)$, med middeltemperaturer på henholdsvis $22,9^{\circ} \mathrm{C}\left(73^{\circ} \mathrm{F}\right)$ og $21,2^{\circ} \mathrm{C}\left(70^{\circ} \mathrm{F}\right)$.) Angående oliven ved Jouf, se 'Saudi Arabia Map' på www.scf.use.edu/ muzain/itp104/project/introduction.htm.supplementaryresult. Desværre angiver Migahid, A.M., 1989: Flora of Saudi Arabia, ii, Riyad, 74, der identificerer Olea europaeana som dyrket, kun distributionen af den vilde sort.

${ }^{24}$ Jf. Crone op. cit., 104, 139; Heck op. cit., 573 (der fremstiller indbyggerne i Mekka som folk, der transporterer olie fra Syrien med kamelkaravane som en tidlig version af 'the mobile oil corporation'). Oliven associeres også med Syrien i al-Dînawarî, 1953: The Book of Plants, a-z, B. Lewin (ed.), Uppsala og Wiesbaden (Uppsala Universitets Årsskrift), no. 466, se under 'zaytûn.'

${ }^{25}$ Som det så ofte er tilfældet med tekniske termer gives der forskellige forklaringer og oversættelser. Hovedpointen her er deres tekniske art.

${ }^{26}$ Waines op. cit., $41 \mathrm{f}$.

27 Torrey, C.C., 1892: The Commercial-Theological Terms in the Koran, Leiden, 2n; og for en nærmere undersøgelse Barthold, W.W., 1929: "Der Koran und das Meer," i Zeitschrift der Deutschen Morgenländischen Gesellschaft.

${ }^{28}$ Torrey hævder, at sura 106 "might well be the words of a tradesman to his fellows, calling on them to recognize the goodness of Allah in prospering their winter and summer caravans" (op. cit., 2), og Heck har også den opfattelse, at "the Qu'rân speaks of annual trading caravans to Yemen and Syria" (op. cit., 572). Men dette er simpelthen en eksegetisk fortolkning af 106:2, og kun én ud af mange mulige (jf. Crone op. cit., 205ff).

${ }^{29}$ Angående alt dette, se Torrey op. cit., 8ff. 
${ }^{30}$ I 52:21 synes enhver mand at være pantsat (rahîn) forstået på den måde, at han er sikker på, at Gud vil godtgøre ham fuldt ud for hans gode gerninger.

${ }^{31}$ Deraf udtrykket ashâb al-yamîn i sura 74:39, hvor hver eneste sjæl er pantsat "except for those of the right hand"

${ }^{32}$ Torrey op. cit., 22f, 32f, med andre metaforer, der har med vejning at gøre på s. 15.

${ }^{33}$ Når dommens dag kaldes den dag, hvor der ikke er nogen bay' (14:31, igen i 2:254, som er medinensisk), synes betydningen at være, at der ikke vil være mulighed for løskøbelse, snarere end at der ikke vil være mulighed for køb og salg (Torrey op. cit., 42).

${ }^{34}$ Torrey op. cit., $9 f$.

${ }^{35}$ Torrey op. cit., $13 \mathrm{f}$.

${ }^{36}$ Denne sura er mekkansk, men som henvisningen til den hellige krig viser, er slutningen henvendt til et politisk aktivt samfund; det er desuden forskelligt fra den tidligere del af suraen ved ikke at have noget rim. Alle versopdelinger af Koranen lader hele tekststykket stå som et enkelt, påfaldende langt, vers (jf. Spitaler, A., 1935: Die Verszählung des Koran, München, 66: jeg skylder Michael Cook denne henvisning).

${ }^{37}$ Skiftet bemærkes af Torrey op. cit., 35 .

${ }^{38}$ Angående dateringen af 73:20, se ovenfor, note 36.

${ }^{39}$ Sura 35 klassificeres som mekkansk, men dette bestemte tekststykke afspejler et samfund af troende (uden at forudsætte politisk uafhængighed).

Patricia Crone er professor i islamisk historie, Institute for Advanced Study, Princeton, USA. 